loss of vitamin C : (1) no tomatoes should be discarded merely because they are small or unripe; (2) unripe tomatoes when being made into chutney should not be cut too finely, and should be put immediately into strong vinegar to which sugar should be added without undue delay.

Frank Wokes. JOAN G. ORGAN.

'Ovaltine' Research Laboratories, King's Langley, Herts.

${ }^{1}$ NATURR, 149, 271 (1942).

NATURE, 149, 499 (1942).

NATURB, 149, 697 (1942).

\section{Estimation of Moisture in Living Tissue}

IN view of the statements made in recent letters in NATURE regarding the estimation of moisture by distillation with an immiscible liquid, and the rela. tionship of such figures to those obtained by oven drying, the results we have obtained recently may be of interest.

Comparison has been made of the apparent 'moisture content' of dehydrated vegetables by several methods: (a) distillation with toluene (Dean and Stark $^{2}$ ), (b) vacuum oven at $70^{\circ} \mathrm{C}$. and less than $50 \mathrm{~mm}$. pressure, (c) hot-air oven at $115^{\circ} \mathrm{C}$., and $(d)$ steam oven at $96^{\circ} \mathrm{C}$.

The results will be reported in full elsewhere, but in general they bear so little resemblance to each other as to give serious cause to doubt whether the figure for 'moisture' returned in many analyses has any significance unless the method is specified. The Dean and Stark method gave results higher than the vacuum oven, but lower than the hot-air oven, and for carrots, onions and cabbages it gave no indication of reaching a constant figure even after thirteen hours distillation. Potatoes and parsnips, on the other hand, gave a constant figure fairly quickly. The loss of weight in the vacuum oven became constant in about 5-8 hours for all vegetables, the other ovens requiring 8-16 hours for onions, parsnips and potatoes, but showing little approach to constancy with carrots and cabbage. This latter effect appears to be due to changes in the structure of the plant materials during the heating, for they change considerably in colour in both the hot-air and steam ovens, although not in the vacuum oven. The standard error of the mean was lowest in the vacuum oven, higher in the steam oven, and much higher in the hot-air oven.

As examples of the variations found the following figures may be quoted.

\begin{tabular}{|c|c|c|c|c|}
\hline & \multicolumn{4}{|c|}{ 'Moisture' by } \\
\hline & $\begin{array}{l}\text { Hot-air } \\
\text { oven } \\
\left(115^{\circ}\right)\end{array}$ & $\begin{array}{l}\text { Steam } \\
\text { oven } \\
\left(96^{\circ}\right)\end{array}$ & $\begin{array}{c}\text { Vacuum } \\
\text { oven } \\
\left(70^{\circ}\right)\end{array}$ & $\begin{array}{l}\text { Toluene } \\
\text { distillation }\end{array}$ \\
\hline Carrots & $15 \cdot 08$ & $8 \cdot 52$ & $5 \cdot 45$ & $11 \cdot 2$ \\
\hline Cabbage & $16 \cdot 05$ & $12 \cdot 04$ & $5 \cdot 44$ & $11 \cdot 1$ \\
\hline Potato (v. Factor) & $11 \cdot 98$ & $10 \cdot 37$ & $10 \cdot 50$ & $11 \cdot 5$ \\
\hline
\end{tabular}

School of Agriculture,

E.IG. HaLLSWORTH.

University of Sydney. June 29. ${ }^{2}$ Holt, P. F., Callow, H. J., NATURE, 148, 755;(1941); Warne, L. G. C.,

'Dean and Stark, J. Ind. Eng.YChem., 12, 486】(1920).

\section{Anemotaxis in Soft-skinned Animals}

LITTLE is known about the effect of wind on the orientation of animals on the ground. Some insects resting in exposed places will often head upwind ${ }^{2}$. The newt Triton toniatus walks in the same direction as an artificial air current ${ }^{2}$. Riders and airmen are familiar with the fact that horses tend to stand with their backs to a strong wind.

Experimenting with slugs (Agriolimax reticulatus, Arion subfuscus and hortensis) on a turning table, it was observed that after several minutes turning they would always bend their heads against the direction of the passive rotation, regardless of whether they were originally facing towards the centre or the periphery. It was assumed that this reaction was caused by the air moving over one side of the body. Animals were then exposed on a stationary table to artificial air currents coming from a tube. (1) If the current was so gentle as to be scarcely perceptible on the observer's cheeks, the tentacles of the animals, after an initial retraction, expanded towards the source of the current, the animal frequently raising its head from the table and testing the current with all four tentacles. (2) However, a strong air current coming from one side, best directed a little from above and behind, led to the contraction of the nearer tentacle or even the whole head, and to a subsequent sharp turning of the animal to face down wind. The most likely mechanism for both reactions depends on the wind bending the animal, and its tentacles in particular $^{1}$. According to the intensity of the wind, propioreception of the bending force may then induce the positive or the negative reaction. This assumption is supported by the observation that a much stronger wind is needed to cause the bulky Limax maximus to turn away than is required for the smaller species.

Similar reactions as in the slugs may be observed in Helix hortensis and aspersa, earthworms and maggots (of Calliphora, Drosophila).

The positive anemotaxis described may be important for the animal's olfactory orientation. The negative reaction may reduce the rate of desiccation or lead the animal to shelter. H. KaLmus.

Department of Biometry,

University College, London, at Rothamsted Experimental Station, Harpenden, Herts. Sept. 29.

1Fraenkel and Gunn, "The Orientation of Animals", pp. 258 and 260 (Oxford, 1940); Kalmus, NATURE, 150, 405 (1942). 'Czeloth, H., Z. vergl. Physiol., 18, 74 (1930).

\section{The Public Schools in Great Britain}

I sHould like to make a few comments upon the recent communication by the number of distinguished men of science discussing the Public Schools in Great Britain ${ }^{1}$.

I do not know how much first-hand and up-to-date knowledge the signatories have of the working of the Public Schools; in the course of the communication they lay down a number of general propositions without producing evidence in support of them--for example, that men brought up in the Public School tradition are "out of touch with modern social realities", and that the teaching of science under the conditions existing in these Schools "tends to become an esoteric cult, isolated from social purpose". Those who have had long experience of teaching in Public Schools, 